\title{
Perilaku Dan Musuh Alami Kupu Endemik Sulawesi Papilio blumei: Acuan dalam Konservasi
}

\author{
SULFIANTO ALIAS ${ }^{1}$, RC HIDAYAT SOESILOHADI ${ }^{2}$ \\ ${ }^{1}$ Jurusan manaejemen Pertanian, Politeknik Pertanian Negeri Samarinda, Jalan Sam Ratulangi, Samarinda, Indonesia. \\ ${ }^{2}$ Fakultas Biologi, Universitas Gadjah Mada, Teknika Selatan, Yogyakarta, Indonesia. \\ *email: sulfianto.alias@mail.ugm.ac.id; hid_soesi@yahoo.com
}

Manuscript received: 14 Desember 2014 Revision accepted: 27 Januari 2015

\begin{abstract}
Papilio blumei is an endemic butterfly of Sulawesi and especially in Bantimurung Bulusaraung National Park. This research was to observed of the behaviour and natural enemies of $P$. blumei in Bantimurung Bulusaraung National Park. The behaviour of the insect were mating, foraging, competiting, ovipositing and mud-puddling. Life table was used for analysis of mortality factors, therefore the number of mortality was analyzed by key-factors formulation. The result indicated that mating strategies is patrolling. Foraging activity of the sixth instar was the highest compared to the other instars and the lowest one activity of the prapupa stadium of $P$. blumei. Nectar host plants for the imago of butterfly were Sarcosephalum latifolius and Eugenia sp. There was Scudderia sp. as an interspesific competitor for larval P. blumei. The intraspesific competitor of the imago stage was male of $P$. blumei. Female $P$. blumei laid eggs on abaxial leaf E.hupehensis and the eggs hatched after six days. The larva of $P$. blumei has a overheating behaviour and the adults has a mud puddling. The natural enemies of P.blumei is Trichogramma sp., with k value $=0.381$, Pteromalus sp., with k value $=0.125$ and Formica sp., with k value $=0.096$.
\end{abstract}

Keywords: Papilio blumei, behaviour, conservation

\section{LATAR BELAKANG}

Sulawesi memiliki keragaman jenis kupu yang tertinggi di Indonesia (Collins and Morris, 1985). Salah satu famili kupu yang banyak diperdagangkan dan dikoleksi berasal dari Famili Papilionidae (swallowtails butterfly) (Xiushan et al., 2006). Intensitas perdagangan kupu yang tinggi menyebabkan turunnya densitas populasi beberapa jenis kupu terutama kupu endemik.

Salah satu jenis kupu yang belum banyak diteliti dan saat ini populasinya semakin berkurang yaitu $P$. blumei. Kupu ini merupakan kupu endemik Sulawesi (Wright and De Jong, 2003) dan fase larva hanya hidup pada satu jenis tumbuhan inang yaitu Euodia sp (Igarashi, 1993). Di kawasan wisata Taman Nasional Bantimurung Bulusaraung (TN.BaBul), kupu ini menjadi primadona kolektor. Kupu ini juga menjadi icon ketika memasuki gerbang wisata TN.BaBul (Gambar I). Masyarakat masih melakukan penangkapan secara langsung (tidak melalui penangkaran)

Pihak TN.BaBul telah mencoba melakukan penangkaran namun populasi kupu P.blumei belum mampu untuk ditangkarkan (Hasil observasi, 2012). Hal ini disebabkan karena belum diketahui perilaku kupu serta musuh alaminya.

Penelitian ini bertujuan untuk menjelaskan perilaku dan musuh alami kupu P.blumei dan diharapkan diperoleh hasil yang menunjang kesuksesan untuk penangkaran $P$. blumei.

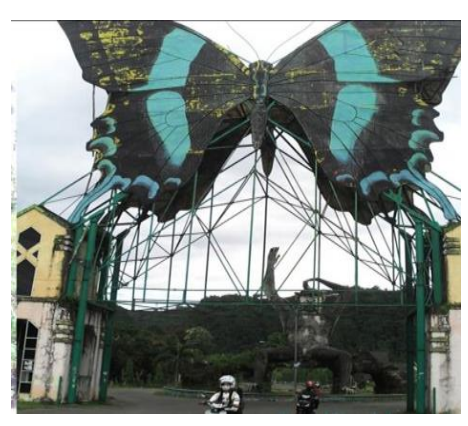

Gambar 1. Icon P.blumei pada pintu gerbang kawasan wisata TN. Bantimurung Bulusaraung (Dokumentasi pribadi, 2012)..

\section{METODE}

\section{Waktu dan Lokasi Penelitian}

Penelitian ini dilaksanakan selama lima bulan, yaitu Agustus hingga Desember 2012. Penelitian dilakukan di kawasan Taman Nasional Bantimurung Bulusaraung, Sulawesi Selatan.

\section{Pengamatan Perilaku}

Perilaku yang diamati mencakup mating behaviour, feeding behaviour, kompetisi, oviposisi, dan mud puddling. Mating behaviour diamati secara langsung di alam. Mating behaviour kupu terdiri atas dua strategi yaitu perching dan patrolling (Mastright and Rosariyanti, 2005). Strategi perching merupakan strategi kawin kupu jantan melalui metode menunggu imago betina pada tempat tertentu misalnya babatuan. Pengamatan strategi perching dilakukan secara langsung dengan menggunakan binokular pada tempat yang lebih tinggi. Perilaku 
patrolling merupakan strategi kawin imago jantan melalui metode berkeliling pada area tertentu untuk mencari betina. Perilaku patrolling diamati dengan menggunakan kupu imitasi dan trap warna. Pengamatan mating behaviour dilakukan dengan mengamati aktifitas imago jantan pagi hingga sore hari (09.00 hingga 15.00). Penentuan mating behaviour melalui perhitungan frekuensi aktiftas jantan yang peching dan patrolling.

Pengamatan feeding behaviour larva $P$. blumei dilakukan dengan menghitung aktifitas makan fase larva pada waktu tertentu pada masing-masing instar. feeding behaviour Imago diamati selama dua jam dengan menghitung frekuensi mengunjungi nektar pada waktu tersebut dengan cara mencari bukit yang tertinggi hingga keseluruhan aktiftas pencarian nektar yang dilakukan oleh kupu dapat teramati dengan baik secara harian. Jenis tanaman nektar yang dikunjungi pada waktu tersebut kemudian dicatat dan diidentifikasi.

Kompetisi Intraspesifik dilakukan dengan menggunakan kupu imitasi $P$. blumei betina sebagai perangkap datangnya kupu jantan. Kupu diletakkan di atas semak, dan dilakukan perekaman video kupu jantan yang datang mengunjungi kupu betina. Tanda kompetisi yaitu munculnya dua imago $P$. blumei jantan secara bersamaan sehingga terjadi kontes antar jantan dari imago P.blumei. Kompetisi interspesifik imago P.blumei diamati dengan mengamati tanaman nektar yang dikunjungi oleh imago P.blumei dan kupu lain. Pada tahap larva, kompetisi intraspesifik dan interspesifik diamati secara langsung pada tanaman inang larva P.blumei.

Pengamatan perilaku oviposisi diamati secara langsung di alam dengan menghitung jumlah telur yang dihasilkan. Pengamatan juga dilakukan dengan mengamati letak atau posisi telur terhadap daun, apakah terdapat pada bagian abaksial daun, adaksial daun, atau terletak pada batang daun. Waktu bertelur pada pagi hari, siang hari, ataukah sore hari dengan cara mengamati frekuensi kupu meletakkan telur. Durasi fase telur diamati dengan memeliharan telur dalam kotak tangkaran dan menghitung lamanya fase telur yang dimulai sejak telur diletakkan oleh betina hingga telur berubah menjadi larva.

Perilaku mud-puddling diamati di lokasi mata air sungai. mud puddling merupakan perilaku kupu hinggap pada tanah bermineral dan mineral ini membantu spermatogenesis (Beck et al., 1999). Perilaku mudpuddling terjadi pada siang hari pada tanah yang basah.
Pengamatan dilakukan secara langsung. Jumlah imago yang melakukan mud-puddling dan frekuensi mud puddling kemudian dicatat. Sampel tanah kemudian dibawa ke laboratorium untuk dianalisis mineral yang terkandung di dalamnya.

\section{Faktor Mortalitas Oleh Musuh Alami}

Pengamatan musuh alami kupu P.blumei dilakukan pada seluruh tahap perkembangan kupu menggunakan life table (Xiushan et al,. 2006). Penggunaan life tabel didahului dengan memelihara tumbuhan inang P.blumei (Euodia hupehensis) pada lokasi yang telah ditentukan.Telur P.blumei yang telah dikoleksi kemudian dipelihara pada tumbuhan inang dalam tangkaran. Telur diamati setiap hari hingga telur berubah menjadi larva, larva menjadi pupa, hingga mencapai imago. Jumlah yang mengalami kematian $(\mathrm{dx})$ kemudian dicatat beserta faktor penyebab kematiannya $(\mathrm{dx} F)$.

Jenis musuh alami didokumentasikan dengan menggunakan DSLR camera dengan tipe lensa macrolens. Hasil dokumentasi kemudian diidentifikasi.

\section{HASIL DAN PEMBAHASAN}

\section{Hasil Penelitian}

Perilaku Кири P.blumei

P.blumei memiliki strategi kawin patrolling, yaitu strategi kawin dari imago jantan berkeliling mencari imago betina pada lokasi tertentu (Fischer et al., 2001). Pada Tabel 1 menunjukkan bahwa frekuensi imago jantan yang tertangkap menggunakan trap kupu imitasi betina.

Larva Kupu P.blumei memiliki aktifitas feeding yang sangat tinggi pada instar ke enam, dengan frekuensi feeding sembilan kali per hari dan aktifitas paling rendah pada fase prapupa dengan aktifitas makan satu kali per hari (Tabel 1) .

Fase dewasa Kupu P.blumei mengunjungi dua jenis tanaman nektar, yaitu bissuhu (Sarcosephalus latifolius) dan jambu hutan (Eugenia $s p$ ) dengan frekuensi kunjungan enam kali perhari,

Kompetisi Interspesifik ditemukan pada fase larva. Kompetitor larva meliputi Scudderia sp. sedangkan Kompetitor pada fase dewasa berasal dari kupu jenis swordstail, yaitu Graphium sarpedon. Kompetisi intraspesifik ditemukan pada kupu P.blumei jantan.

Tabel 1. Perilaku Kupu P.blumei

\begin{tabular}{|c|c|c|c|c|c|c|c|}
\hline Perilaku & $\begin{array}{c}\text { Frekuensi imago } \\
\text { jantan menerapkan } \\
\text { strategi kawin }\end{array}$ & $\begin{array}{c}\text { Jumlah daun atau } \\
\text { bunga yang } \\
\text { dikonsumsi larva dan } \\
\text { prapupa/hari }\end{array}$ & $\begin{array}{l}\text { Frekuensi oviposisi } \\
\text { telur pada tumbuhan } \\
\text { inang Konsentrasi }\end{array}$ & $\begin{array}{c}\mathrm{Na}^{+} \\
(\mathrm{cmol} / \mathrm{kg})\end{array}$ & $\begin{array}{c}\mathrm{NH}_{4}^{+} \\
(\%)\end{array}$ & $\begin{array}{c}\mathrm{Cl}^{-} \\
(\mathrm{ppm})\end{array}$ & $\begin{array}{c}\mathrm{PO}_{4} \\
(\mathrm{ppm})\end{array}$ \\
\hline
\end{tabular}

\begin{tabular}{lc}
\hline Mating Behaviour & \\
a. Perching & 15 \\
b. Patrolling & 1
\end{tabular}




\begin{tabular}{|c|c|c|c|c|c|c|c|}
\hline Perilaku & $\begin{array}{l}\text { Frekuensi imago } \\
\text { jantan menerapkan } \\
\text { strategi kawin }\end{array}$ & $\begin{array}{c}\text { Jumlah daun atau } \\
\text { bunga yang } \\
\text { dikonsumsi larva dan } \\
\text { prapupa/hari } \\
\end{array}$ & $\begin{array}{l}\text { Frekuensi oviposisi } \\
\text { telur pada tumbuhan } \\
\text { inang Konsentrasi }\end{array}$ & $\begin{array}{c}\mathrm{Na}^{+} \\
(\mathrm{cmol} / \mathrm{kg})\end{array}$ & $\begin{array}{c}\mathrm{NH}_{4}^{+} \\
(\%)\end{array}$ & $\begin{array}{c}\mathrm{Cl}^{-} \\
(\mathrm{ppm})\end{array}$ & $\begin{array}{r}\mathrm{PO}_{4} \\
(\mathrm{ppm})\end{array}$ \\
\hline \multicolumn{8}{|l|}{ Feeding Behaviour } \\
\hline a. Larva Instar I & - & 2 & - & - & - & - & - \\
\hline b. Larva Instar II & - & 4 & - & - & - & - & - \\
\hline c. Larva Instar III & - & 4 & - & - & - & - & - \\
\hline d. Larva Instar IV & - & 7 & - & - & - & - & - \\
\hline e. Larva Instar V & - & 7 & - & - & - & - & - \\
\hline f. Larva Instar VI & - & 9 & - & - & - & - & - \\
\hline g. Prapupa & - & 1 & - & - & - & - & - \\
\hline b. Imago & - & $6^{*}$ & - & - & - & - & - \\
\hline \multicolumn{8}{|l|}{ Oviposisi } \\
\hline a. Abaxial daun & - & - & 14 & - & - & - & - \\
\hline b. Adaxial daun & - & - & 0 & - & - & - & - \\
\hline c. Batang & - & - & 0 & - & - & - & - \\
\hline \multicolumn{8}{|l|}{ Mud-Puddling } \\
\hline $\begin{array}{l}\text { Konsentrasi unsur/ } \\
\text { senyawa }\end{array}$ & - & - & - & 0.851 & 0,045 & 0.084 & 21.55 \\
\hline
\end{tabular}

Ket $: *=$ Jenis tumbuhan inang adalah Sarcocephalus latifolius dan Eugenia sp.

Kompetitor intraspesifik biasanya terjadi ketika kupu P.blumei betina hinggap (strategi patrolling). Secara bersamaan dua ekor kupu jantan mendekati betina dengan berkompetisi dengan cara saling kontes di udara.

Jumlah telur yang diletakkan lima hingga tujuh telur pada masing-masing pohon. Telur yang diletakkan jika berdasar pada filotaksis daun pada batang diletakkan secara acak. Terkadang pada cabang tersier, sekunder, bahkan pada cabang primer.

Penyerapan mineral ini mencakup $\mathrm{Na}, \mathrm{NH}_{4}, \mathrm{Cl}^{-}$dan $\mathrm{PO}_{4}$, yang masing-masing kadarnya adalah $0.851 \mathrm{cmol} / \mathrm{kg}$, 0,045\%, $0.084 \mathrm{ppm}$, dan $21.55 \mathrm{ppm}$. Kupu P.blumei banyak memiliki perilaku mud-puddling pada musim kemarau.

\section{Faktor Mortalitas oleh Musuh alami}

Musuh alami kupu, terdapat pada seluruh fase perkembangan, pada telur terdapat musuh alami berupa parasitoid Trichogramma, dan Cecak Terbang (Draco volans). Pada fase pupa, terdapat Parasitoid Pteromalus puparum yang menyerang pupa pada umur awal, selain itu juga terdapat semut merah (Formica $s p$ ). Pada fase dewasa ditemukan semut merah (Tabel 2).

Tabel 2. Tabel Kehidupan Populasi Alami P. blumei

\begin{tabular}{cccc}
\hline $\mathrm{x}$ & $\mathrm{lx}$ & $\mathrm{dxF}$ & $\mathrm{k}$ \\
\hline Telur & 12 & Trichogramma sp. & 0.381 \\
L1 - L3 & 5 & Formica sp. & 0.096 \\
L4 - L6 & 4 & & \\
Pupa & 4 & Pteromalus sp. & 0.125 \\
Imago & 3 & &
\end{tabular}

\footnotetext{
Ket: $x=$ Fase Perkembangan $\mathrm{k}=$ key factor $l x=$ Jumlah individu yang hidup L1-L6 = Instar 1-6 $d x F=$ Musuh alami penyebab kematian
}

Mortalitas tertinggi pada Kupu P.blumei terjadi pada fase telur, dengan nilai $k$ sebesar 0.381 (Tabel 2). Mortalitas umumnya disebabkan karena parasitoid telur.

\section{Pembahasan}

P. blumei memiliki strategi kawin patrolling. Pada tipe patrolling, imago jantan akan berkeliling mencari dan mendekati kupu betina. Imago betina berperilaku menghindar ketika bertemu imago jantan. Perilaku ini disebut sebagai perilaku kontes di udara. Perilaku yang sama terjadi pada kupu lain seperti P.ullyses (Mastright dan Rosariyanto 2005) dan Cressida cressida (Orr and Kitching, 2010).

Feeding behaviour terlihat sejak larva. Telur akan menetas menjadi larva instar I. Larva ini tidak secara langsung memakan daun E.hupehensis (tumbuhan inang larva P.blumei), larva instar I awalnya menyesuaikan diri terhadap lingkungan dengan berjalan mengelilingi daun tumbuhan inang. Sehari dalam tahap penyesuaian, larva kemudian memakan daun muda tumbuhan. Larva memakan bagian tengah daun. Gigitan larva Instar I tidak seluruhnya memotong bagian daun, akan tetapi terbatas pada permukaan atas daun. Setelah larva mencapai instar II (3-4 hari) kemudian larva dapat memotong keseluruhan bagian daun.

Aktifitas makan tertinggi terdapat pada larva instar ke VI sedangkan aktifitas makan terendah terdapat pada fase prapupa. Ketika perubahan instar larva (yang ditandai dengan molting), larva berperilaku memakan kulit hasil molting. Perilaku ini juga terdapat pada kupu Papilio ullyses, ketika memasuki instar terakhir, larva cenderung memakan sisa kulit hasil molting (Emmel 1976)

Imago $P$. blumei mengkonsumsi nektar dari jenis Eugenia sp (Famili Myrtaceae) dan Sarcocephalus latifolius (Famili Rubiaceae), kedua jenis tanaman ini memiliki tabung corolla yang relatif panjang sehingga memiliki kecocokan dengan panjang proboscis $P$. blumei. 
Moulds (1977) berpendapat bahwa anggota Tribe Graphiini umumnya memiliki tanaman inang dari anggota Famili Lauracea dan Annonaceae, dan Papilionini mengkonsumsi tanaman dari anggota Famili Rutaceae, serta anggota Tribe Troidini mengkonsumsi nektar dari bunga anggota Famili Aristolochiaceae.

Banyaknya kompetitor pemakan daun E.hupehensis juga menyebabkan semakin sedikit telur yang diletakkan pada tanaman inang ini. Hal ini disebabkan karena semakin banyak daun yang rusak karena dimakan oleh kompetitor

Telur $P$. blumei diletakkan pada abaksial daun E.hupehensis. Ini bertujuan untuk melindungi dari air hujan dan terhindar dari predator. Sebelum bertelur, $P$. blumei melakukan orientasi yang bertujuan untuk pengenalan tanaman inang dengan menggunakan tarsi. Perilaku orientasi ini dilakukan 7 hingga 9 kali sebelum telur diletakkan pada permukaan bawah daun. Orientasi bertujuan menentukan letak telur yang akan dikeluarkan (oviposition) berdasarkan kadar metabolit sekunder pada daun.

Renwick and Chew (1994), menyatakan bahwa terdapat beberapa tahapan sebelum kupu melakukakan oviposition, yaitu pencarian, orientasi, pertemuan, landing, evaluasi dengan kontak, dan penerimaan atau penolakan. Reseptor sensori yang berperan terhadap perilaku ini terletak pada tarsi, antenna, proboscis, serta ovipositor.

P. blumei memiliki perilaku mud-puddling pada musim kemarau. Beck et al. (1999) men

ulis bahwa beberapa lokasi seperti di California, perilaku mud-puddling hanya terjadi pada musim kering. Pada bioma stepa di Turki, jumlah kupu sangat banyak pada musim kering.

Musuh alami $P$. blumei ditemukan pada seluruh fase perkembangan. Musuh alami larva yang peneliti temukan adalah parasitoid telur Trichogramma. Parasitoid ini menyerang telur $P$. blumei yang berumur sehari atau dua hari (umur awal). Biasanya tiga sampai empat parasitoid yang keluar dari dalam telur yang telah terinfeksi.

Nagarkatti (1974) menuliskan bahwa Trichogramma yang menyerang telur Papilio adalah T.nagarkatti. Parasitoid ini menyerang telur Papilio xuthus dan Papilio memnon, yang merupakan anggota tribe yang sama dengan $P$. blumei.

Fase Pupa juga memiliki musuh alami parasitoid Pteromalus puparum. Selain itu terdapat jenis semut Formica sp. Pteromalus puparum adalah parasitoid yang menyerang selama fase pupa. Pupa yang diserang yaitu pupa pada umur 2 hari. Tanda serangan yaitu berubahnya warna pupa, yang awalnya hijau muda, menjadi hijau kehitaman. Parasitoid ini juga menyerang Papilio xuthus dan Papilio demodocus (Yamasaki et al., 1980)

Di alam, nilai mortalitas dapat lebih tinggi dari nilai yang didapatkan karena di alam musuh alami semakin banyak, tidak terbatas seperti pada pemeliharaan dalam tangkaran (Mardiani et al., 2006).

Berdasarkan kurva survivorship, serangga memiliki kurva survivorship tipe III, yaitu serangga banyak menghasilkan keturunan (Telur) namun memiliki mortalitas yang sangat tinggi pada awal fase kehidupan (Rockwood 2006). Di dalam melakukan penangkaran, paranet yang digunakan harus memiliki pori yang kecil, dengan tujuan agar tidak memungkinkan parasitoid masuk ke dalam penangkaran. Ukuran Parasitoid kurang lebih $0.5 \mathrm{~mm}$, sehingga sebaiknya ukuran mesh dari paranet lebih kecil dari $0.5 \mathrm{~mm}$.

\section{KESIMPULAN}

Strategi kawin $P$. blumei adalah Patrolling, pada fase larva aktifitas makan tertinggi pada instar VI, dan terendah pada fase Prapupa, tanaman yang dikunjungi yaitu Sarcocephalum latifolius, dan Eugenia sp., kompetitor interspesifik meliputi Graphium sarpedon dan Scudderia sp., kompetitor intraspesifik yaitu sesama jantan $P$. blumei, telur diletakkan dibagian bawah daun dengan masa inkubasi selama enam hari, P.blumei memiliki perilaku mud-puddling .

Musuh alami $P$. blumei terdiri dari Trichogramma sp. dengan nilai $\mathrm{k}=0.381$, Pteromalus $\mathrm{sp}$. dengan nilai $k=$ 0.125 , dan Formica sp. dengan nilai k $=0.096$.

\section{UCAPAN TERIMA KASIH}

Terima kasih kepada Dr. Suwarno Hadisusanto dan Dr. Siti Sumarmi selaku penguji naskah tesis dan TIM BPPDN DIKTI tahun 2011 yang telah memberikan dana penelitian mahasiswa program strata dua.

\section{DAFTAR PUSTAKA}

Beck J, Eva, M.E \& Konrad, F. (1999). Mud-puddling behaviour in tropical butterfies: in search of proteins or minerals?. Oecologia. 119, 140-148.

Collins, N.M. \& Morris, M.G. (1985). "Threatened swallowtails butterflies of the world: The IUCN red data books". IUCN gland. Switzerland.

Emmel T.C. (1976). "Butterflies: Their World, Their Life Cycle, Their Behaviour:. Thames And Hudson. London.

Fischer, Klaus, \& Fiedler, K. (2001). Resource-based territoriality in the butterfly Lycaena hippothoe and environmentally induced behavioural shifts. Animal Behaviour. 61.4 : 723-732.

Igarashi S. (1993). Life history of Achilllides blumei and Euthalia amanda. Butterflies. 8. 38-43

Mardiani A, Tri, A. \& Mohammad, A. (2006). Morfologi dan Siklus Hidup Kupu Raja (Troides helena. Lepidoptera:Papilionidae) Yang Dipelihara Di Dalam Penangkaran. Prosiding Seminar Nasional Entomoligi. Bogor. Page 527-532.

Mastright V \& Rosariyanto. (2005). "Panduan lapangan kupu kupu di Memberamo". Conservation International. Jakarta.

Moulds N.S. (1977). Bibliography of the Australian Butterflies(Lepidoptera:Hesperioidea and Papilionoidea)1773-1973, Australian Entomological Press: Greenwich, New South Wales.

Nagarkatti S. (1974). A New Species Oftrichogramma (Hymenoptera: Trichogrammatidae) Parasitic of Papilio SPP. In Japan. Oriental Insect. Vol.8(3):391-393 
Orr, R. \& Kitching, W.L. (2010). "The Butterliefs of Australia”. Crows Ness. New South Wales.

Renwick J.A. \& Chew, F.S. (1994). Oviposition Behaviour In Lepidoptera. Annu. Rev. Entomol. 39: 377-400.

Rockwood, L. (2006). "Introduction to Population Ecology". Blackwell Publishing. UK.

Wright, V. \& De Jong, R. (2003). The butterflies of Sulawesi: annotated checklist for a critical island fauna. Zool. Verh. Leiden. 343: 3-267.
Xiushan L., Yalin, Z., Youqing, L. \& Josef, S. (2006). Life history, life table, habitat, and Conservation of Byasa impediens (Lepidoptera: Papilionidae), Acta ecologica Sinica, 26(10). 3184-3197

Yamasaki, M., Yamaguchi, K. \& Iga, M. (1980). Predation of Papilio xuthus larvae by Polistes wasps in relation to the colony development of the principal predator, Polistes jadwigae Dalla Torre (Hymenoptera: Vespidae). Japanese Journal of Applied Entomology and Zoology. 24(1): 28-30. 